\title{
KEDUDUKAN INFORMED CONSENT DALAM HUBUNGAN DOKTER DAN PASIEN
}

\author{
Irfan \\ Fakultas Hukum Universitas Muhammadiyah Sumatera Utara \\ Jl. Kapt. Mukhtar Basri Nomor 3, Medan - Sumatera Utara \\ Email: irfan@umsu.ac.id
}

\begin{abstract}
Abstrak
Informed consent dapat didefinisikan sebagai pernyataan pasien atau secara sah mewakilinya dalam bentuk perjanjian tentang rencana tindakan medis yang diajukan oleh dokter setelah menerima informasi yang cukup untuk dapat membuat perjanjian atau penolakan. Penandatanganan formulir persetujuan tertulis hanya merupakan penegasan dari apa yang telah disepakati sebelumnya. Tujuan dari penjelasan lengkap adalah agar pasien menentukan keputusannya sesuai dengan pilihan pasien (keputusan berdasarkan informasi). Jenis penelitian dalam makalah ini adalah penelitian hukum normatif. Sifat dari penelitian ini adalah deskriptif analitis, yang merupakan penelitian yang menggambarkan, memeriksa, menjelaskan dan menganalisis peraturan hukum yang terkait dengan posisi persetujuan informasi dalam hubungan antara dokter dan pasien. Hasil dari penelitian ini adalah bahwa sebelum melakukan tindakan medis, pasien memiliki hak untuk mendapatkan informasi tentang tindakan medis yang harus dilakukan kepadanya sebagaimana diatur dalam Peraturan Menteri Kesehatan (Permenkes) Nomor 290 Tahun 2008 tentang Persetujuan Tindakan Medis. Jika dilihat dari segi bentuk persetujuan berdasarkan informasi terdiri dari persetujuan yang tidak Sah (dianggap diberikan) dan persetujuan tertulis (dinyatakan), keberadaan persetujuan berdasarkan informasi sangat penting dalam hubungan antara dokter dan pasien di mana persetujuan berdasarkan informasi merupakan dasar atau landasan untuk mengambil tindakan medis terhadap pasien.
\end{abstract}

\section{Kata Kunci: Kedudukan, Informed Consent, Dokter, Pasien}

\section{Abstract}

Informed Consent can be defined as a statement of the patient or legitimately representing him in the form of an agreement on a medical action plan submitted by a doctor after receiving sufficient information to be able to make an agreement or rejection. The signing of the written informed consent form is only an affirmation of what was previously agreed. The purpose of the complete explanation is so that the patient determines his decision according to the patient's choice (informed decision). The type of research in this paper is normative legal research. The nature of this research is descriptive analytical, which is a study that describes, examines, explains and analyzes a legal regulation related to the informed consentration position in the relationship between doctors and patients. The results of this study are that before carrying out a medical action the patient has the right to obtain information on medical actions to be carried out to him as stipulated in the Minister of Health Regulation (Permenkes) No. 290 of 2008 concerning Medical Action Approval, if viewed in terms of form, the informed consent consists of Imflied consent (considered given) and expressed consent (stated), the presence of informed consent is very important in the relationship between doctors and patients where informed consent is the basis or foundation to take medical action against patients. 
Jurnal Ilmu Hukum

FAKULTAS HUKUM UMSU
Kedudukan Informed Consent...(Irfan)

Volume 3 Nomor 2, Juli-Desember 2018, 154-165 DOI: https://doi.org/10.30596/dll.v3i2.3155

\section{Keywords: Position, Informed Consent, Doctor, Patient PENDAHULUAN}

Kesehatan merupakan bagian terpenting dalam kehidupan manusia. Produktivitas dan aktivitas seseorang dipengaruhi oleh kondisi kesehatan orang tersebut. Dengan kesehatan orang dapat berpikir dengan baik dan dapat melakukan aktivitas secara optimal. Ketika kesehatan seseorang terganggu, mereka akan melakukan berbagai cara untuk dapat sehat kembali. Salah satunya adalah dengan cara berobat dan mendapatkan tindakan kedokteran di sarana-sarana pelayanan kesehatan yang tersedia seperti puskesmas, klinik, dan rumah sakit.

Dokter dan pasien adalah dua subjek hukum yang terkait dalam hukum kedokteran, keduanya membentuk baik hubungan medis maupun hubungan hukum. Hubungan medis dan hubungan hukum antara dokter dan pasien adalah hubungan yang objeknya adalah pemeliharaan kesehatan pada umumnya dan pelayanan kesehatan pada khususnya. Dalam melaksanakan hubungan antara dokter dan pasien, pelaksanaan antara keduanya selalu diatur dengan peraturan - peraturan tertentu agar tejadi keharmonisan dalam pelaksanaannya.

Pasien sebagai pihak yang membutuhkan pelayanan kesehatan menyerahkan sepenuhnya peliharaan dan perawatan kesehatannya kepada seorang dokter di pihak lain. Pada saat seorang pasien datang kepada dokter dan menyatakan keluhannya, dan dokter bersedia mendengarkan keluhan pasien, maka di situ sudah terjadi hubungan perikatan antara kedua belah pihak. Kedatangan pasien ke tempat praktek dokter, rumah sakit, atau sarana kesehatan lainnya dapat diartikan sebagai usaha untuk mengajukan penawaran kepada dokter untuk dimintai pertolongan dalam mengatasi keluhan yang dideritanya. Begitu pula sebaliknya, dokter juga akan melakukan pelayanan medis berupa rangkaian tindakan yang meliputi diagnosa dan tindakan medis. Hubungan hukum ini selanjutnya disebut transaksi, yang dalam hukum perdata disebut perjanjian, dan dalam pelayanan kesehatan disebut "perjanjian terapeutik" atau transaksi terapeutik.

Hubungan hukum antara dokter dan pasien yang dilaksanakan dengan rasa kepercayaan dari pasien terhadap dokter disebut dengan istilah transaksi terapeutik. Dalam hukum perikatan dikenal adanya 2 (dua) macam perjanjian, yaitu:

1. Inspanningverbintenis, yaitu perjanjian upaya, artinya kedua belah pihak berjanji atau sepakat untuk berdaya upaya secara maksimal untuk mewujudkan apa yang diperjanjikan.

2. Resultaatverbintenis, yaitu suatu perjanjian yang akan memberikan resultaat atau hasil yang nyata sesuai dengan apa yang diperjanjikan.

Perjanjian terapeutik atau transaksi terapeutik termasuk dalam inspanningverbintenis atau perjanjian upaya, karena dokter tidak mungkin menjanjikan kesembuhan kepada pasien, yang dilakukan dokter adalah melakukan pelayanan kesehatan sebagai upaya untuk menyembuhkan pasien. Dalam melakukan upaya ini, dokter harus melakukan dengan penuh kesungguhan dengan mengerahkan seluruh kemampuan dan keterampilan yang dimilikinya dengan berpedoman kepada standar profesi. Dalam perjanjian terapeutik, tidak seperti halnya perjanjian biasa, terdapat hal-hal khusus. Disini pasien merupakan pihak yang meminta 
Jurnal Ilmu Hukum FAKULTAS HUKUM UMSU
Kedudukan Informed Consent...(Irfan) DOI: https://doi.org/10.30596/dll.v3i2.3155

pertolongan pertolongan sehingga relatif lemah kedudukannya dibandingkan dokter untuk mengurangi kelemahan tersebut telah bertambah prinsip yang dikenal dengan inform consent, yaitu suatu hak pasien untuk mengizikan dilakukannya suatu tindakan medis.

Akhir-akhir ini keberadaan informed consent dalam medis semakin merupakan suatu kelengkapan, keharusan yang dibuat oleh dokter sebelum melaksanakan tindakan medis yang direncaanakan meskipun ada pengecualian membuat informed consent sebelum tindakan medis pada keadaan-keadaan tertentu. Namun demikian masih dirasakan belum semua dokter melaksanakannya menurut ketentuan yang ada, mungkin disebabkan tidak tersedianya formulir informed consent yang isinya menurut kebutuhan disiplin ilmu kedokteran tertentu, atau tidak menyempatkan membuatnya.Dua topik utama dalam informed consent yaitu informasi dan persetujuan mempunyai variasi yang luas dan agak kompleks, melibatkan berbagai unsure yaitu dokter -pasien - keluarga.

Pada hakikatnya Informed Consent adalah suatu proses komunikasi antara dokter dan pasien tentang kesepakatan tindakan medis yang akan dilakukan dokter terhadap pasien. Penandatanganan formulir informed consent secara tertulis hanya merupakan pengukuhan atas apa yang telah disepakati sebelumnya. Tujuan penjelasan yang lengkap adalah agar pasien menentukan sendiri keputusannya sesuai dengan pilihan dia sendir (informed decision). Karena itu, pasien juga berhak untuk menolak tindakan medis yang dianjurkan. Pasien juga berhak untuk meminta pendapat dokter lain (second opinion), dan dokter yang merawatnya.

\section{METODE PENELITIAN}

Jenis penelitian ini adalah penelitian hukum normatif. Penelitian normatif dapat dikatakan juga dengan penelitian sistematik hukum sehingga bertujuan mengadakan identifikasi terhadap pengertian-pengertian pokok/dasar dalam hukum mengenai kedudukan informed consent terhadap hubungan dokter dengan pasien (Soerjono Soekanto, 1985, h.15). Metode penelitian hukum normatif adalah untuk mengetahui atau mengenal apakah dan bagaimanakah hukum positifnya mengenai suatu masalah yang tertentu. Penelitian ini juga dapat menjelaskan dan menerangkan kepada orang lain dan bagaimana hukumnya mengenai peristiwa atau masalah tertentu (C. F. G Sunaryati Hartono, 1994, h. 140).

Adapun sifat penelitian ini adalah deskriptif analisis yang merupakan suatu penelitian yang menggambarkan, menelaah, menjelaskan dan menganalisis suatu peraturan hukum (Soerjono Seokanto, 1986, h. 63). Penelitian ini akan menguji, mengkaji ketentuan-ketentuan penerapan terkait dengan permasalahan dalam penelitian ini. Jenis penelitian ini mempergunakan metode yuridis normatif, dengan pendekatan kualitatif. Penelitian yuridis normatif adalah penelitian dengan penelusuran dokumen atau lebih banyak dilakukan terhadap data yang bersifat sekunder yang ada di perpustakaan.

\section{PEMBAHASAN}

\section{Pengertian Informed Consent}


Jurnal Ilmu Hukum FAKULTAS HUKUM UMSU
Kedudukan Informed Consent...(Irfan) DOI: https://doi.org/10.30596/dll.v3i2.3155

Pelayanan medis sebagai salah satu dari unsur pelayanan yang sangat berperan penting didalam pemberian pelayanan kesehatan kepada pasien. Di dalam pelayanan medis itu terdapat para tenaga medis sebagai pemberi pelayanan (medical providers) dan pasien sebagai penerima pelayanan (medical receivers). Masing-masing pihak mempunyai hak dan kewajiban yang harus dihormati. Didalam pelaksanaan profesinya, tenaga medis harus berlaku jujur dan menjaga agar pasien tidak sampai dirugikan karenanya, disamping itu tenaga medis juga harus mengetahui hal-hal yang berhubungan dengan informed consent sebagai dasar atau persetujuan (izin) bagi tenaga medis didalam memberikan tindakan medik kepada pasien.

Pada hakikatnya Informed Consent adalah suatu proses komunikasi antara dokter dan pasien tentang kesepakatan tindakan medis yang akan dilakukan dokter terhadap pasien (ada kegiatan penjelasan rinci oleh dokter), sehingga kesepakatan lisan pun sesungguhnya sudah cukup. Penandatanganan formulir Informed consent secara tertulis hanya merupakan pengukuhan atas apa yang telah disepakati sebelumnya. Informed consent terdiri dari dua kata yaitu 'informed' yang berarti informasi atau keterangan dan "consent" yang berarti persetujuan atau memberi izin. Jadi pengertian informed consent adalah suatu persetujuan yang diberikan setelah mendapat informasi. Dengan demikian informed consent dapat di definisikan sebagai pernyataan pasien atau yang sah mewakilinya yang isinya berupa persetujuan atas rencana tindakan kedokteran yang diajukan oleh dokter setelah menerima informasi yang cukup untuk dapat membuat persetujuan atau penolakan. Persetujuan tindakan yang akan dilakukan oleh Dokter harus dilakukan tanpa adanya unsur pemaksaan.

Istilah Bahasa Indonesia informed consent diterjemahkan sebagai persetujuan tindakan medik yang terdiri dari dua suku kata Bahasa Inggris yaitu Inform yang bermakna Informasi dan consent berarti persetujuan. Sehingga secara umum informed consent dapat diartikan sebagai persetujuan yang diberikan oleh seorang pasien kepada dokter atas suatu tindakan medik yang akan dilakukan, setelah mendapatkan informasi yang jelas akan tindakan tersebut. Informed Consent menurut Permenkes No.585/Menkes/Per/IX/1989, Persetujuan Tindakan Medik adalah Persetujuan yang diberikan oleh pasien atau keluarganya atas dasar penjelasan mengenai tindakan medik yang akan dilakukan terhadap pasien tersebut.

Tujuan dari informed consent menurut J. Guwandi adalah :

a. Melindungi pasien terhadap segala tindakan medis yang dilakukan tanpa sepengetahuan pasien

b. Memberikan perlindungan hukum kepada dokter terhadap akibat yang tidak terduga dan bersifat negatif, misalnya terhadap risk of treatment yang tak mungkin dihindarkan walaupun dokter sudah mengusahakan semaksimal mungkin dan bertindak dengan sangat hati-hati dan teliti.

Ketiadaan informed consent dapat menyebabkan tindakan malpraktek dokter, khususnya bila terjadi kerugian atau intervensi terhadap tubuh pasiennya. Hukum yang umum diberbagai Negara menyatakan bahwa akibat dari ketiadaan informed consent setara dengan kelalaian/keteledoran. Akan tetapi, dalam beberapa hal, ketiadaan informed consent tersebut 
Jurnal Ilmu Hukum

FAKULTAS HUKUM UMSU
Kedudukan Informed Consent...(Irfan) DOI: https://doi.org/10.30596/dll.v3i2.3155

setara dengan perbuatan kesengajaan, sehingga derajat kesalahan dokter pelaku tindakan tersebut lebih tinggi.

Tindakan malpraktek dokter yang dianggap setara dengan kesengajaan adalah sebagai berikut :

a. Pasien sebelumnya menyatakan tidak setuju terhadap tindakan dokter, tetapi dokter tetap melakukan tindakan tersebut.

b. Jika dokter dengan sengaja melakukan tindakan misleading (menyesatkan) tentang risiko dan akibat dari tindakan medis yang diambilnya.

c. Jika dokter dengan sengaja menyembunyikan risiko dan akibat dari tindakan medis yang diambilnya.

d. Informed consent diberikan terhadap prosedur medis yang berbeda secara substansial dengan yang dilakukan oleh dokter.

\section{Hak Pasien Atas Informasi}

Hak pasien sebenarnya merupakan hak yang asasi yang bersumber dari hak dasar individu dalam bidang kesehatan, (the right of self determination), meskipun sebenarnya sama fundamentalnya, namun hak atas pelayanan kesehataan sering dianggap lebih mendasar, dalam hubungan dokter-pasien,secara relatif pasien berada dalam posisi yang lemah, kekurang mampuan pasien untuk membela kepentingannya dalam situasi pelayanan kesehatan menyebabkan timbulnya kebutuhan untuk mempermasalahkan hak-hak pasien dalam menghadapi para professional kesehatan.

Hak-hak untuk memperoleh informasi merupakan hak asasi pasien yang paling utama bahkan dalam tindakan khusus diperlukan informed consent (persetujuan tindakan medis). Hubungan antara informed consent dan tindakan medis yang akan dilakukan oleh dokter dapat dikatakan bahwa informed consent merupakan komponen utama yang mendukung adanya tindakan medis tersebut.

Pasien berhak mengetahui segala sesuatu yang berkaitan dengan keadaan penyakit, yakni tentang diagnosis, tindak medik yang akan dilakukan, risiko dari dilakukan atau tidak dilakukannya tindak medik tersebut. Informasi medik yang berhak diketahui pasien, termasuk pula identitas dokter yang merawat serta aturan- aturan yang berlaku di rumah sakit tempat ia dirawat (misalnya tentang tarif dan cara pembayaran pada rumah sakit tersebut) Dokter dapat menahan informasi medik, apabila hal tersebut akan melemahkan daya tahan pasien.

Sejak berlakunya Peraturan Menteri Kesehatan (Permenkes) Nomor 290 tahun 2008 tentang Persetujuan Tindaka Kedokteran, maka sebelum melakukan suatu tindakan medik maka pasien memiliki hak untuk mendapatkan informasi terhadap tindakan medik yang akan dilakukan kepadanya, dalam permenkes ini juga memberikan perlindungan terhadapa hak pasien untuk menolak pengobatan medik karena sebelum dilakukan sebuah tindakan medik maka Dokter wajib mendapat persetujuan dari pasien atau orang yang berhak memberikan izin terhadap tindakan yang akan dilakukan pada pasien.

Informasi yang harus diberikan kepada pasien atau keluarga terdekat diatur di dalam 
Jurnal Ilmu Hukum FAKULTAS HUKUM UMSU
Kedudukan Informed Consent...(Irfan)

Volume 3 Nomor 2, Juli-Desember 2018, 154-165 DOI: https://doi.org/10.30596/dll.v3i2.3155

Pasal 7 ayat 3 yaitu sekurang-kurangnya mencakup : (a) Diagnosis dan tata cara tindakan kedokteran; (b) Tujuan tindakan kedokteran yang dilakukan; (c) Alternatif tindakan lain, dan risikonya; (d) Risiko dan komplikasi yang mungkin terjadinya; dan (e) Prognosis terhadap tindakan yang dilakukan (f) Perkiraan pembiayaan.

Penjelasan tentang diagnosis dan keadaan kesehatan pasien dapat meliputi temuan klinis dari hasil pemeriksaan medis hingga saat tersebut, diagnosis penyakit atau dalam hal belum dapat ditegakan, maka sekurang-kurangnya diagnosis kerja dan diagnosis banding, indikasi atau keadaan klinis pasien yang membutuhkan dilakukannya tindakan kedokteran, Prognosis (kemungkinan hasil perawatan) apabila dilakukan tindakan dan apabila tidak dilakukan tindakan. Hal ini diatur dalam Pasal 8 ayat 1 Permenkes Nomor 290 Tahun 2008.

Penjelasan tentang tindakan kedokteran yang dilakukan meliputi tujuan tindakan kedokteran yang dapat berupa tujuan preventif, diagnostic, terapeutik, ataupun rehabilitatif. Tata cara pelaksanaan tindakan apa yang dialami pasien selama dan sesudah tindakan, serta efek samping atau kenyamanan yang mungkin terjadi, alternatif tindakan lain berikut kelebihan dan kekurangannya dibandingkan dengan tindakan yang direncanakan, risiko dan komplikasi yang mungkin terjadi pada masing-masing alternatif tindakan, perluasan tindakan yang mungkin dilakukan untuk mengatasi keadaan darurat akibat risiko dan komplikasi tersebut atau keadaan tak terduga lainnya, hal ini diatur dalam Pasal 8 ayat 2 Permenkes Nomor 290 Tahun 2008 tentang Persetujuan Tindakan Kedokteran.

Penjelasan tentang risiko dan komplikasi tindakan kedokteran adalah semua risiko dan komplikasi yang dapat terjadi mengikuti tindakan kedokteran yang dilakukan kecuali risiko dan komplikasi yang sudah menjadi pengetahuan umum, risiko dan komplikasi yang sangat jarang terjadi atau yang dampaknya sangat ringan, risiko dan komplikasi yang tidak dapat dibayangkan sebelumnya (unforeeable). Hal ini diatur dalam Pasal 8 ayat 3 Nomor 290 Tahun 2008 tentang Persetujuan Tindakan Kedokteran. Penjelasan tentang prognosis meliputi prognosis tentang hidup matinya (ad vitam), prognosis tentang fungsinya (ad functinam), Prognosis (kemungkinan hasil perawatan) tentang kesembuhannya (ad sanationam). Hal ini diatur dalam Pasal 8 ayat 4 Permenkes Nomor 290 Tahun 2008 tentang Persetujuan Tindakan Kedokteran.

\section{Bentuk/Jenis Informed Consent}

Pelayanan medis sebagai salah satu dari unsur pelayanan yang sangat berperan penting didalam pemberian pelayanan kesehatan kepada pasien. Di dalam pelayanan medis itu terdapat para tenaga medis sebagai pemberi pelayanan (medical providers) dan pasien sebagai penerima pelayanan (medical receivers). Masing-masing pihak mempunyai hak dan kewajiban yang harus dihormati. Didalam pelaksanaan profesinya, tenaga medis harus berlaku jujur dan menjaga agar pasien tidak sampai dirugikan karenanya, disamping itu tenaga medis juga harus mengetahui hal-hal yang berhubungan dengan informed consent sebagai dasar atau persetujuan (izin) bagi tenaga medis didalam memberikan tindakan medik kepada pasien. 
Jurnal Ilmu Hukum FAKULTAS HUKUM UMSU
Kedudukan Informed Consent...(Irfan)

Volume 3 Nomor 2, Juli-Desember 2018, 154-165 DOI: https://doi.org/10.30596/dll.v3i2.3155

Persetujuan Tindakan Medik (informed consent) melahirkan perjanjian terapeutik. Perjanjian terapeutik adalah perjanjian antara dokter dengan pasien yang memberikan kewenangan kepada dokter untuk melakukan kegiatan memberikan pelayanan kesehatan kepada pasien berdasarkan keahlian dan keterampilan yang dimiliki oleh dokter tersebut. Dalam Mukadimah Kode Etik Kedokteran Indonesia yang dilampirkan dalam Keputusan Menteri Kesehatan RI Nomor 434 /Men.Kes /X/1983 tentang Berlakunya Kode Etik Kedokteran Indonesia Bagi Para Dokter di Indonesia, mencantumkan tentang transaksi terapeutik sebagai berikut "Yang dimaksud transaksi terapeutik adalah hubungan antara dokter dengan pasien dan penderita yang dilakukan dalam suasana saling percaya (konfidensial) serta senantiasa diliputi oleh segala emosi, harapan dan kekhawatiran makhluk insansi".

Hubungan hukum dalam transaksi terapeutik tersebut timbullah hak dan kewajiban masing-masing pihak, baik bagi pihak pasien maupun pihak dokter. Suatu perjanjian dikatakan sah bila memenuhi persyaratan sebagaimana diatur dalam Pasal 1321 KUHPerdata yang berbunyi "Tiada sepakat yang sah apabila sepakat itu diberikan karena kekhilafan atau diperolehnya dengan paksaan atau penipuan".

Sesuai pasal tersebut di atas dapat disimpulkan bahwa secara yuridis keabsahan suatu perjanjian ditentukan oleh kesepakatan para pihak yang mengikatkan dirinya, dengan tanpa adanya kekhilafan, paksaan ataupun penipuan. Sepakat ini merupakan persetujuan yang dilakukan oleh kedua belah pihak dimana kedua belah pihak mempunyai persesuaian kehendak yang dalam transaksi terapeutik sebagai pihak pasien setuju untuk diobati oleh dokter, dan dokterpun setuju untuk mengobati pasiennya. Agar kesepakatan ini sah menurut hukum, maka didalam kesepakatan ini para pihak harus sadar (tidak ada kekhilafan) terhadap

kesepakatan yang dibuat, tidak boleh ada paksaan dari salah satu pihak, dan tidak boleh ada penipuan didalamnya. Untuk itulah diperlukan adanya informed consent atau yang juga dikenal dengan istilah Persetujuan Tindakan Medik.

Ada 2 bentuk Persetujuan Tindakan Medis, yaitu:

a. Implied consent (dianggap diberikan)

Umumnya implied consent diberikan dalam keadaan normal, artinya dokter dapat menangkap persetujuan tindakan medis tersebut dari isyarat yang diberikan/dilakukan pasien. Demikian pula pada kasus emergency sedangkan dokter memerlukan tindakan segera sementara pasien dalam keadaan tidak bisa memberikan persetujuan dan keluarganya tidak ada ditempat, maka dokter dapat melakukan tindakan medik terbaik menurut dokter.

b. Expressed consent (dinyatakan)

Dapat dinyatakan secara lisan maupun tertulis. Dalam tindakan medis yang bersifat invasive dan mengandung resiko, Dokter sebaiknya mendapatkan persetujuan secara tertulis, atau yang secara umum dikenal di rumah sakit sebagai surat izin operasi.

Informed consent merupakan hak pasien yang termuat dalam Pasal 32 Undang-Undang Nomor 44 Tahun 2009 tentang Rumah Sakit yang berbunyi : 
Jurnal Ilmu Hukum

FAKULTAS HUKUM UMSU
Kedudukan Informed Consent...(Irfan)

Volume 3 Nomor 2, Juli-Desember 2018, 154-165 DOI: https://doi.org/10.30596/dll.v3i2.3155

a. Mendapat informasi yang meliputi diagnosis dan tata cara tindakan medis, tujuan tindakan medis, alternatif tindakan, risiko dan komplikasi yang mungkin terjadi, dan prognosis terhadap tindakan yang dilakukan serta perkiraan biaya pengobatan;

b. Memberikan persetujuan atau menolak atas tindakan yang akan dilakukan oleh tenaga kesehatan terhadap penyakit yang dideritanya.

Penyampain informasi yang tidak efektif dapat menimbulkan berbagai masalah. Mungkin saja dokter sudah memberikan informasi yang cukup kepada pasien. Namun, berhubung pasien kurang atau tidak memahami bahasa yang digunakan oleh dokter, maka dipermasalahkan tentang informed-nya. Pasien memang menandatangani surat persetujuan, tetapi pasien mengakui bahwa pasien tidak diberi informasi dan pasien tidak mengerti apa yang disetujui. Mungkin saja yang menurut dokter sudah diberi informasi yang cukup, menurut pasien belum cukup karena pasien tidak mengerti bahwa apa yang telah dikatakan dokter itu adalah sebuah informasi untuk dirinya. Seringkali pasien hanya menganggukkan kepalanya seakan-akan mengerti, tanpa peryataan sebab apa yang akan ditanyakan saja dia tidak tahu. Dokter yang mengganggap anggukan pasien sebagai tanda mengerti akan menyerahkan formulir persetujuan tindakan medis dan pasien membubuhkan tanda tangannya. Hal ini sering terjadi dalam hal pengetahuan pasien yang minim.

\section{Dasar Tindakan Medis Terhadap Pasien}

Persetujuan tindakan Kedokteran telah diatur dalam Pasal 45 Undang-Undang Nomor 29 Tahun 2004 tentang Praktek Kedokteran. Sebagaimana dinyatakan setiap tindakan kedokteran atau kedokteran gigi yang akan dilakukan oleh dokter atau dokter gigi terhadap pasien harus mendapat persetujuan. Persetujuan sebagaimana dimaksud diberikan setelah pasien mendapat penjelasan secara lengkap, sekurang-kurangnya mencakup: diagnosis dan tata cara tindakan medis, tujuan tindakan medis yang dilakukan, alternatif tindakan lain dan risikonya,risiko dan komplikasi yang mungkin terjadi, dan prognosis terhadap tindakan yang dilakukan. Disebutkan didalamnya bahwa setiap tindakan kedokteran atau kedokteran gigi yang mengandung risiko tinggi harus diberikan dengan persetujuan tertulis yang ditandatangani oleh yang berhak memberikan persetujuan.

Mendudukkan hubungan tenaga medis dengan pasien yang mempunyai landasan hukum, dapat dimulai dengan pasal 1313 KUH Perdata "Suatu perjanjian adalah suatu perbuatan dengan mana satu orang atau lebih mengikatkan dirinya terhadap satu orang atau lebih". Dengan demikian kedudukan pasien dan tenaga medis dalam pelayanan kesehatan seharusnya seimbang. Di satu sisi pasien membutuhkan tenaga medis untuk mengatasi masalah kesehatannya, sedangkan di lain pihak tenaga medis membutuhkan pasien untuk mendapatkan penghasilan sekaligus untuk mempraktekkan ilmu medis yang telah dipelajarinya di bangku pendidikan.

Masing-masing pihak, dalam hal ini tenaga medis yang dalam posisi pemberi pelayanan (medical providers) dan pasien sebagai penerima pelayanan (medical receivers) mempunyai 
Kedudukan Informed Consent...(Irfan) DOI: https://doi.org/10.30596/dll.v3i2.3155

hak dan kewajiban yang harus dihormati. Dalam ikatan demikianlah masalah informed consent atau Persetujuan Tindakan Medik/Kedokteran ini muncul. Di mana, seorang pasien atau keluarganya harus di berikan informasi atau penjelasan yang sejelas-jelasnya dari tenaga medis terhadap tindakan medik yang akan dilakukan terhadap diri si pasien, agar supaya memberikan persetujuan atau izin kepada tenaga medis tersebut. Dengan demikian akibat persetujuan itu akan terjadi "perjanjian" antara dua pihak. Kedua belah pihak bersetuju dan berjanji untuk melaksanakan sesuatu dalam bidang pengobatan atau kesehatan. Akibat perjanjian ini akan terjadi "perikatan" antara dua pihak yaitu pasien dan tenaga medis tersebut.

Sudah menjadi pengetahuan umum bahwa tenaga medis sangat jarang meminta persetujuan dari pasien apabila ingin melaksanakan rangkaian upaya penyembuhan pasien, kecuali dalam hal tindakan pembedahan dan tindakan yang mempunyai resiko medis yang sangat tinggi. Persetujuan itupun juga diminta oleh tenaga medis tanpa penjelasan yang sejelas-jelasnya dan kadang kala ada yang terkesan dipaksakan, apalagi kalau pasien tersebut berobat dengan memakai kartu Jaminan Kesehatan Masyarakat Miskin atau sejenisnya. Di dalam praktek terlihat bahwa hubungan antara tenaga medis dengan pasien masih sangat timpang yang mana tenaga medis masih memiliki posisi dominan sedangkan pasien hanya bersifat pasif menunggu dan terkesan pasrah terhadap apa yang akan dilakukan tenaga medis terhadapnya.

Sesuai ketentuan tentang informed consent jelaslah bahwa di dalam menentukan pengobatan terhadap diri pasien, tenaga medis harus meminta persetujuan baik lisan atau tertulis, tergantung dari berat-ringannya risiko yang akan dihadapi si pasien dan tenaga medis di dalam melakukan tindakan pengobatan. Oleh karena di dalam pasal 52 huruf a dan d Undang-undang Praktik Kedokteran dijelaskan bahwa pasien, dalam menerima pelayanan pada praktik kedokteran, mempunyai hak mendapatkan penjelasan secara lengkap tentang tindakan medis sebagaimana di maksud dalam pasal 45 ayat (3) dan di samping itu pula pasien berhak menolak tindakan medik. Oleh karena itu, informed consent atau Persetujuan Tindakan Medik/Kedokteran merupakan keharusan bagi tenaga medik di dalam merencanakan upaya pengobatan terhadap pasien.

Peraturan Menteri Kesehatan Republik Indonesia Nomor 290/Menkes/Per/III/ 2008 tentang persetujuan tindakan Kedokteran dinyatakan dalam Pasal 1, 2, dan 3 yaitu:

Pasal 1:

Persetujuan tindakan kedokteran adalah persetujuan yang diberikan oleh pasien atau keleuarga terdekat setelah mendapat penjelasan secara lengkap mengenai tindakan kedokteran atau kedokteran gigi yang akan dilakukan terhadap pasien. Keluarga terdekat adalah suami atau istri, ayah atau ibu kandung, anak-anak kandung, saudarasaudara kandung atau pengampunya.

Pasal 2:

a. Semua tindakan kedokteran yang akan dilakukan terhadap pasien harus mendapat persetujuan 
Jurnal Ilmu Hukum

FAKULTAS HUKUM UMSU
Kedudukan Informed Consent...(Irfan)

Volume 3 Nomor 2, Juli-Desember 2018, 154-165 DOI: https://doi.org/10.30596/dll.v3i2.3155

b. Persetujuan sebagaimana dimaksud pada ayat 1 dapat diberikan secara tertulis maupun lisan

c. Persetujuan sebagaimana dimaksud pada ayat 1 diberikan setelah pasien mendapat penjelasan yang diperlukan tentang perlunya tindakan kedokteran dilakukan.

Pasal 3:

a. Setiap tindakan kedokteran yang mengandung risiko tinggi harus memperoleh persetujuan tertulis yang ditandatangani oleh yang berhak memberikan persetujuan.

b. Tindakan kedokteran yang tidak termasuk dalam ketentuan sebagaimana dimaksud pada ayat 1 dapat diberikan dengan persetujuan lisan.

c. Persetujuan tertulis sebagaimana dimaksud pada ayat 1 dibuat dalam bentuk pernyataan yang tertuang dalam formulir khusus yang dibuat untuk itu.

Peraturan Informed Consent apabila dijalankan dengan baik antara Dokter dan pasien akan sama-sama terlindungi secara Hukum. Tetapi apabila terdapat perbuatan diluar peraturan yang sudah dibuat tentu dianggap melanggar Hukum. Dalam pelanggaran Informed Consent telah diatur dalam pasal 19 Permenkes Nomor 290 Tahun 2008 tentang Persetujuan Tindakan Kedokteran, dinyatakan terhadap dokter yang melakukan tindakan tanpa Informed Consent dapat dikenakan sanksi berupa teguran lisan, teguran tertulis sampai dengan pencabutan Surat Ijin Praktik.

Informed consent di Indonesia juga di atur dalam peraturan berikut:

a. Undang-Undang Republik Indonesia Nomor 23 tahun 1992 tentang Kesehatan jo Undang Undang Nomor36 Tahun 2009 Tentang Kesehatan

b. Kode Etik Rumah Sakit Indonesia (KODERSI).

c. Peraturan Menteri Kesehatan RI Nomor 585/Men.Kes/Per/IX/1989 tentang Persetujuan Tindakan Medis.

d. Peraturan Menteri Kesehatan RI Nomor 1419/Men.Kes/Per/X/2005

e. tentang Penyelanggaraan Praktik Kedokteran.

f. Surat Keputusan PB IDI ( Ikatan Dokter Indonesia ) No.319/PB/A4/88.

\section{KESIMPULAN DAN SARAN \\ Kesimpulan}

Informed consent dapat di definisikan sebagai pernyataan pasien atau yang sah mewakilinya yang isinya berupa persetujuan atas rencana tindakan kedokteran yang diajukan oleh dokter setelah menerima informasi yang cukup untuk dapat membuat persetujuan atau penolakan. Sebelum melakukan suatu tindakan medik maka pasien memiliki hak untuk mendapatkan informasi terhadap tindakan medik yang akan dilakukan kepadanya sebagaimana yang diatur dalam Peraturan Menteri Kesehatan (Permenkes) No. 290 tahun 2008 Tentang Persetujuan Tindakan Medis, jika dilihat dari segi bentuknya maka informed consent terdiri dari imflied consent (dianggap diberikan) dan expressed consent (dinyatakan), kehadiran informed consent sangat penting dalam hubungan dokter dan pasien dimana informed consent merupakan dasar atau landasan bagi dokter untuk melakukan tindakan medis terhadap pasien. 


\section{Saran}

Bahwa pengetahuan informed consent bagi setiap pasien yang akan diberikan suatu tindakan medis sangatlah penting. Hal ini dikarenakan untuk memberikan kedudukan hukumnya yang jelas terkait dengan hak dan kewajibannya sebagai seorang pasien. Sehingga dokter yang akan melakukan suatu tindakan medis mengetahui batasan-batasan atas tindakan medis yang akan diambilnya. Sebaliknya juga bagi seorang dokter, informed consent bukan hanya sekedar informasi di atas kertas yang telah ditanda tangani oleh seorang pasien, namun suatu informasi yang memberikan batasan bagi seorang dokter dalam mengambil tindakan medis. Kedudukan informed consent sangat jelas di mata hukum, oleh karena itu dengan memberikan sosialisasi atas pentingnya informed consent ini akan memberikan kesadaran bagi pasien dan dokter dalam hubungan hukum bagi kedua belah pihak tersebut. 


\section{DAFTAR PUSTAKA}

Amri, Amril. (1997). Bunga Rampai Hukum Kesehatan, Jakarta: Widya Medika.

Biben, Achmad. (2005). Alternatif Bentuk inform consent dalam praktik dan penelitian kedokteran. Bandung: FK UNPAD.

Guwandi, J. (2005). Rahasia Medis. Jakarta: Penerbit Fakultas Kedokteran UI.

Konsil Kedokteran Indonesia. (2006). Komunikasi Efektik Dokter-Pasien. Jakarta: KKI.

M, Chrisdiono. (1996). Pernak-Pernik Hukum Kedokteran:Melindungi Pasien dan Dokter. Jakarta: Widya Medika.

M, Chrisdiono., \& Achadiat. (2006). Dinamika Etika dan Hukum Kedokteran Dalam Tantangan Zaman. Jakarta: Penerbit Buku Kedokteran.

Peraturan Menteri Kesehatan Republik Indonesia Nomor 1419/Menkes/Per/X/2005 Tentang Penyelenggaraan Praktik Dokter dan Dokter Gigi.

Peraturan Menteri Kesehatan RI Nomor 585/Men.Kes/Per/IX/1989 tentang Persetujuan Tindakan Medis.

Purwohadiwardoyo, Al. (1989). Etika Medis. Yogyakarta: Kanisius. 